\title{
The Social Factors Influencing Undergraduate Females to Study Mathematics and Physics
}

\author{
Atinuke Adeyemi \\ University of Windsor, Canada
}

\section{Doi:10.5901/jesr.2013.v3n8p157}

\begin{abstract}
This study explored the influences of socializers (e.g., parents, teachers, peers, and counsellors) on the university female students' decisions to pursue careers in mathematics-related disciplines. Data were collected through interviews and focus group meeting from six female students in the second to final year from mathematics and physics departments at the mid-size university in Canada. The findings indicate that females made their decisions to pursue careers mainly out of genuine interest in mathematics and science, and that influences from parents and teachers came through encouragement and support, provision of positive learning experiences, and/or by being role models. It is recommended that parents and teachers be aware of how their involvement in both in- and out-of-class activities with children/students may affect female career pursuits in the field of mathematics. Supports should be put in place for females both during their studies and after they start working in these fields.
\end{abstract}

Keywords: Social factors, gender and mathematics, undergraduate females, choice of study, socializers

\section{Introduction}

This study aimed at identifying and exploring social factors that contribute to the decision of undergraduate female Canadian students to pursue studies in mathematics-related disciplines. Specifically, it focused on the role that socializers (e.g., parents, teachers, peers, and counsellors) play in the career-related decision making of young females. In the United States and in Canada, female students seem hesitant to engage in career paths that require advanced mathematics skills, such as pure mathematics, computer science, engineering, and physics, despite their levels of attainment and participation in mathematics courses that match those of their male counterparts (Cavanagh, 2008; Catsambis, 2005; Dick \& Rallis, 1991; Hanna, 2003). This is evident from the growth in females' enrolments in the undergraduate programs in the Canadian universities where the majority of the enrolment remains in the areas of humanities, social, and behavioral sciences whilst their enrolments in mathematics, computer science and information sciences fields continue to decline (Statistics Canada, 2008). Also, women still present as majority in the traditionally female professions and minority in non-traditional occupations both in Canada and the United States. For example, in the United States, women represent $92 \%$ of nurses, $68 \%$ of psychologists, $48 \%$ of biological and life scientists, $26 \%$ of mathematical and computer scientists, and $10 \%$ of engineers (National Science Foundation, 2011). Similarly, in Canada, women represent $87 \%$ of nurses and health-related therapists, $75 \%$ of clerks and other administrators, $64 \%$ of teachers, $57 \%$ of sales and service personnel, and only $22 \%$ of natural scientists, engineers, and mathematicians (Statistics Canada, 2008). Thus, females may not be fully participating in one of the highly promising and expanding areas of the North American economy. This situation indicates that few role models exist for females in non-traditional fields and also raises concerns that need to be addressed at all levels of schooling as well as the workplace. 


\section{Literature Review}

Researchers have attributed female students' unwillingness to pursue careers in mathematicsrelated disciplines to many factors, such as negative attitudes towards mathematics, mathematics stereotyped as a male domain, inappropriate teaching practices, socialisation, limited exposure to after-school activities in mathematics, and lack of knowledge of the need and usefulness of mathematics in career decisions making (American Association of University Women [AAUW], 1998; Boaler 1997; Eccles 1994; Gadalla, 1998; Hanna, 2003; Rogers \& Kaiser 1995). Although studies have examined the reasons for the lack of female participation in mathematics which focused on gender differences (AAUW, 1992; Crombie et al., 2005; Ercikan, McCreith, \& Lapointe, 2005; Ma \& Cartwright, 2003; Kellaghan \& Madaus, 2002; Walkerdine, 1998), most of them were conducted at the high school level and relied upon females' career intentions rather than females' actual career choices. In addition, comparisons have been usually made between female and male students with little research done on finding out about the disparity in motives (if they exist) amongst females who opted for non-traditional career choices. There has been a growing body of research that points to inherent differences within gender groups and therefore question viewing and treating males (Martino, Lingard, \& Mills, 2004) or females (Marlino \& Wilson, 2002; Slater, Guthrie, \& Boyd, 2001) as uniform group. For example, it has been established that females from different racial and ethnic backgrounds also differ in their career expectations and goals.

Researchers have reported that social factors such as socializers and cultural milieu could affect females' enrolment in mathematics. That is, the attitudes and behaviours of parents, teachers, counsellors, and peers have consequences on female enrolment choices in mathematics (AAUW, 1992; Leedy et al., 2003). Research findings also indicate that these social groups think that males will outshine females in subjects such as high school calculus, and as a result, less encouragement is given to females in the pursuit of mathematics (Brush, 1980; Dick \& Rallis, 1991; Meece et al., 1982; Paa \& MacWhirter, 2000)

To this day, very little research has been conducted in Canada on female students pursuing non-traditional careers at the university level. As a result, the explanations for the under representation of female students pursuing careers in mathematics-related disciplines at the university level remain indistinct and need further in-depth research. In 1998, Gadalla cautioned that "it is unlikely that female representation in [mathematics- related careers] will increase in the near future because women continue to account for relatively small proportions of total university enrolment in these fields" (p. 2). For these reasons, females who persevered in the traditionally underrepresented fields of study may prove to be valuable source for research aiming to obtain in depth information on the impact of socializers on career choices of university female students toward mathematics-related disciplines. Therefore, the purpose of this study was to examine the specifically social factors that influenced the decision to pursue mathematics-related disciplines of a group of second to final year undergraduate female students at the mid-size university in Southern Ontario, Canada.

This study was framed around a theoretical model of career choice developed by Dick and Rallis (1991). In this model, between a student's aptitude and her career choice stand several factors that affect the outcome. The socializers play the central role. The perception of socializers, together with the contextual factors (cultural milieu) and past, lived, experiences, are interpreted by the student and in that process form her self-concept and abilities and determine comparative values of pursuit of different careers. On the other hand, students' aptitudes shape their past experiences and both, in turn, can have an effect on socializers' attitudes and expectations for the students. Also, the cultural milieu in which students and socializers dwell influences the attitudes and expectations of socializers, the students' perceptions of attitudes and expectations of socializers, and, eventually, students' self concepts and career values. While Dick and Rallis used surveys and large samples for their study, they recommended that future studies implement interviews with women who have opted for careers in science and engineering, to obtain "a more 
detailed picture of the forces and factors forming their career choices" (p. 291). Accordingly, in this study, the model was adapted to better fit university students (rather than high school students, as it is in its original form) and the interviews were conducted along the variables in the model.

\section{Methods and Procedures}

This study took a form of a qualitative case study. This research design was chosen because the goal was to examine the situation primarily from the participants' perspectives and to gain in-depth understanding of the case (Hancock \& Algozzine, 2006). In particular, Creswell (2009) explains that case study is a method of inquiry that allows for deep exploration of one or more individuals, while Yin (2009) views case study as particularly suitable for answering 'how' and 'why' questions. In addition, the focus of case study research is explained as a "bounded system" (Merriam, 1988, p. 9). This study was bounded by the unit of analysis (the female participants), the context (pursuing mathematics-related disciplines at a mid-size university in southern Ontario), and sampling criteria (involving only second- to final-year undergraduate female students in mathematics and physics).

The convenience non-random sampling method (Cohen, Manion, \& Morrison, 2000; Nardi, 2006) was used to select participants from two departments (Mathematics and Statistics, and Physics) in a Faculty of Science. The participants were six female students in the second to final year from Mathematics and Physics departments at the mid-size university in Ontario, Canada. The participants' ages ranged from 19 to 25; they were all full-time undergraduate students in the Faculty of Science. Although three of the participants were not born in Canada, all of them obtained their high school education in Canada. This gave room for obtaining insights pertinent to female decisions to pursue non-traditional fields in the Canadian educational system. By making sure that the sample consists of participants from years 2-4 from two departments and that data collection was done in a relatively short time, the researcher followed the research approach outlined by Hoepfl (1997), who cautioned qualitative researchers that sampling errors (e.g., insufficient breadth in sampling, changes in participants and procedures over time, and lack of depth in data collection at the research site) may result in distorted findings.

Face-to-face interviews and focus group discussion were the primary methods of data collection used in this study. This is consistent with Mason (2002), who stated that interviews of individuals or groups give the researcher the opportunity to obtain rich, personalised information. After transcribing interview with each participant and the focus group meeting, the emerging themes and patterns in the participants' responses were noted.

In addressing the validity and reliability of the study, two types of data triangulation were used: (a) multiple sources (i.e., multiple participants, and (b) multiple data collection methods (i.e., individual and focus group interviews). I was, from the beginning of the study, mindful of the potential biases arising from my strong educational background in mathematics-related discipline. Thus, I aimed at representing participants' experiences and opinions accurately. The data collected and interpreted were taken back to participants for review to check for accuracy. In addition, an external observer was asked to review the data and the findings so as to ensure that data were not lost through my bias or carelessness. Reliability threats were addressed through documentation. A detailed record was kept of how data were collected and how participants were contacted.

\section{Results}

The findings revealed that the females in this study made their decisions to pursue mathematicsrelated disciplines mostly due to their genuine interest in mathematics and science, which appears to have been stimulated by experiences with these subjects prior to and during high school. This is consistent with previous research (Dick \& Rallis, 1991; Gadalla, 1998; Pertiller, 2006) that states that females' interests influence their intentions to pursue a particular career and that interest is the most common reason influencing females' decision for choosing physics as a career (Ivie \& 
Guo, 2006).

Socializers, specifically parents and teachers, were influential in the females' decisionsthrough encouragement and support and/or by being role models. Positive experiences provided by the teachers included the use of adequate teaching methods. The parents of the females in this study supported and encouraged their daughters' interest in mathematics and science. The females did not only have positive perceptions of their parents' attitudes towards mathematics, but were also brought up in a mathematics-supportive environment from a young age. Based on the participants' recollections, these factors increased their interest in and enjoyment in doing mathematics and science. Parental support and encouragement have also been reported by other researchers (Catsambis, 2005; Dick \& Rallis, 1991; Muller, 1998; Robinson, 2006) as significant, because of their impact on students' attitudes towards mathematics, achievements and participation in mathematics, career aspirations, career-choice development, and future selections of mathematics- and science-related majors. In addition, the females appeared confident in their mathematics abilities; they described mathematics as manageable and felt that they could excel in mathematics-related disciplines. It seems that parents' and teachers' support and actions may have contributed to the females' confidence in mathematics and/or sciences. Also, having more educated mothers and having parents in careers such as engineering seem to have influenced the females' mathematics-related career choices.

\section{Conclusion}

The study contributes to research on females' motivations to pursue mathematics-related disciplines in higher education. It also sheds further light into what can be done by parents, teachers, facilitators of the secondary and postsecondary programs, mathematics course instructors, and care counsellors to increase females' interest and willingness to pursue careers in mathematics-related fields. In conclusion, I suggest that more outreach programs and mathematics-related extracurricular activities, such as math clubs, be organised in schools to engage both students and their parents. Hiring bodies should be made aware of the impact female instructors may have on their female students; they may encourage their new faculty members to become involved in the promotional activities, organization of mathematics/science clubs, and competitions where female involvement would be promoted.

\section{References}

American Association of University Women (AAUW) (1992). How schools shortchange girls. Washington, DC: American Association of University Women Educational Foundation.

American Association of University Women (1998). Gender gaps: Where schools still fail our children. American Association of University Women Educational Foundation.

Boaler, J. (1997). Reclaiming school mathematics: The girls fight back. Gender and Education, 9(3), 285306.

Brush, L.R. (1980). Encouraging Girls in Mathematics. The problem and the solution. Cambridge, MA: ABT Books.

Catsambis, S. (2005). The gender gap in mathematics: Merely a step function? In A. Gallagher and J. Kaufman (Eds.). Gender differences in mathematics. An integrative psychological approach (pp. 220-245) Cambridge, UK: Cambridge University Press.

Cavanaugh, S. (2008). Stereotype of mathematical inferiority still plagues girls. Education Week, 28(1), 9

Cohen, L., Manion, L., \& Morrison, K. (2000). Research methods in education ( $5^{\text {th }}$ ed.). London, UK: Routledge.

Creswell, J. (2009). Research design: Quantitative, qualitative, and mixed methods approaches. ( $3^{\text {rd }}$ Ed). Sage Publications.

Crombie, G., Sinclair, N., Silverthorn, N., Byrne, B.M., Dubois, D. L., \& Trinneer, A. (2005). Predictors of young adolescents' math grades and course enrolment intentions: Gender similarities and 
differences. Sex Roles, 52(5/6), 351-367.

Dick T., \& Rallis S. (1991). Factors and influences on high school students' career choices: Journal for Research in Mathematics Education, 22(4), 281- 292.

Eccles, J. (1994). Understanding women's educational and occupational choices: Applying the Eccles et al. model of achievement-related choices. Psychology of Women Quarterly, 18, 585-609.

Ercikan, K., McCreith, T., \& Lapointe, V. (2005). Factors associated with mathematics achievement and participation in advanced mathematics courses: An examination of gender differences from an international perspective. Schoo/ Science and Mathematics, 105(1), 5-14.

Gadalla T. (1998). Patterns of women's enrolment in university mathematics, engineering and computer science in Canada, 1972-1995. Ontario Institute for Studies in Education of the University of Toronto.

Hancock, D., \& Algozzine, R. (2006). Doing case study research: A practical guide for beginning researchers. New York, NY: Teachers College Press.

Hanna, G. (2003). Reaching gender equity in mathematics education. The Educational Forum, 67(3), 204-214.

Hoepfl, M. C. (1997). Choosing qualitative research: A primer for technology education researchers. Journal of Technology Education, 9(1). Retrieved from http://scholar.lib.vt.edu/ejournals/JTE/v9n1 /hoepfl.html

I vie, R., \& Guo, S. (2006). Women physicists speak Again: The International study of women in physics. In B.K. Artline \& D. Li (Eds.), Women in Physics: The IUPAP International Conference on Women in Physics. American Institute of Physics. Melville, NY.

Kellaghan, T., \& Madaus, G.F. (2002). Teachers' sources and uses of assessment information. In D.F. Robitaille \& A.E. Beaton (Eds.), Secondary analysis of the TIMSS data. Boston, MA: Kluwer Academic Publishers.

Koehler, S.M. (1990). Classroom, Teachers, and Gender differences in Mathematics. In E. Fennema \& G.C. Leder (Eds.), Mathematics and Gender (pp. 128-148). New York: Teachers College Press

Leedy, G., LaLonde, D., \& Runk, K. (2003). Gender equity in mathematics: Beliefs of students, parents, and teachers. Schoo/ Science and Mathematics, 103(6), 285-292.

Mason, J. (2002). Qualitative researching (2 ${ }^{\text {nd }}$ ed.). Thousand Oaks, CA: Sage Publication.

Merriam, S. B. (1988). Case study research in education: A qualitative approach. San Francisco, CA: Jossey-Bass.

Meece, J., Parsons, J., Kaczala, C., Goff, S., \& Futterman, R. (1982). Sex differences in math achievement: Toward a model of academic choice. Psychological Bulletin, 91(2), 324-348.

Muller, C. (1998). Gender differences in parental involvement and adolescents' mathematics achievement. Sociology of Education, 71(4), 256-336.

Nardi, P. M. (2006). Doing survey research: A guide to quantitative methods. (2 ${ }^{\text {nd }}$ ed.). Boston, MA: Pearson Education.

National Science Foundation (NSF) (2011). Women, minorities, and persons with disabilities in sciences and technology. Retrieved from http://www.nsf.gov/statistics/wmpd/figh-1.htm

Paa, H., \& McWhirter, E. (2000). Perceived influences on high school students' current career expectations. The Career Development Quarterly, 49(1), 29-44.

Pelletier, M. (2006). Factors Influencing Women's' Participation in Mathematical disciplines. M.Ed. thesis, Lakehead University, Canada, Retrieved March 11, 2013 from Dissertations \& Theses.

Robinson, J. (2006). Women who chose mathematics: The external and internal factors influencing their participation in a math- related occupation. Unpublished MA Thesis, Concordia University Montreal, Canada.

Rogers, P. \& Kaiser, G. (Eds.) (1995). Equity in mathematics education: Influences of feminism and culture. London: Falmer Press.

Statistics Canada (2008). University enrolment. The Daily, February 7, 2008.

Walkerdine, V. (1998). Counting girls out. Girls and mathematics. Bristol, PA: Falmer Press.

Yin, R. (2009). Case study research: Design and methods ( $4^{\text {th }}$ ed.). Thousand Oaks, CA: Sage 
